\title{
Measurement of methaemalbumin in plasma
}

\author{
K. MURRAY, M. KNIGHT, AND J. A. OWEN \\ From the Departments of Haematology, Surgery and Chemical Pathology, St George's Hospital, London
}

SYNOPSIS Using the method of Chong and Owen (1967), the normal range of methaemalbumin in plasma was 0 to $0.6 \mathrm{mg} / 100 \mathrm{ml}$, expressed as milligrams of haematin per cent. Previous results, using the method of Shinowara and Walters (1963), reported a normal range of 0 to $8.0 \mathrm{mg} / 100 \mathrm{ml}$, but it was expressed as milligrams of haemoglobin percent. The conversion factor from the Shinowara method is as follows: $\mathrm{mg}$ haematin $\%=\mathrm{mg}$ haemoglobin $\% \times 0.04$.

The level of plasma methaemalbumin is elevated after severe intravascular haemolysis (Fairley, 1941; Dacie, 1954) and in some patients with haemorrhagic pancreatitis (Northam, Rowe, and Winstone, 1963). It is formed by the breakdown of haemoglobin to haematin which combines with albumin to give methaemalbumin.

After intravascular haemolysis, haemoglobin released into the plasma from red cells combines with an alpha $a_{2}$ globulin, haptoglobin, to form a complex which is then removed from the circulation (Laurell and Nyman, 1957). If the amount of haemolysis exceeds the capacity of haptoglobin to bind haemoglobin, the free haemoglobin circulates before its excretion by the kidney and some breaks down to haematin giving rise to methaemalbumin. In patients with haemorrhagic pancreatitis, plasma methaemalbumin levels are elevated probably as a result of pancreatic enzyme action on extravasated blood in the haemorrhagic gland (Northam, Winstone, and Banwell, 1965). Haemoglobin released from red cells breaks down locally to haematin which either diffuses into the circulation to form methaemalbumin or, more likely, combines with albumin in the extravascular fluid and passes thence into the circulation.

Of the various quantitative methods available for the measurement of methaemalbumin, probably the most widely used is that of Shinowara and Walters (1963). A disadvantage of this method is that turbidity or background colour of the specimen can invalidate the spectroscopic data. To overcome this difficulty, Chong and Owen (1967) devised a method based on the ability of reducing agents such as sodium dithionite to change the absorption spectrum of methaemalbumin. The purpose of this paper is

Received for publication 19 March 1973. to report the range of normal values for haematin using the method of Chong and Owen.

\section{Methods and Results}

Standard solutions were made by dissolving weighed amounts of haematin (BDH) in a minimum volume of $1 \mathrm{M} \mathrm{NaOH}$ and added immediately to a solution $(4 \% \mathrm{w} / \mathrm{v})$ of human serum albumin. To $2 \mathrm{ml}$ aliquots of plasma or standard solution was added $1 \mathrm{ml}$ of phosphate buffer (1 M pH 7.4). The mixture was centrifuged for five minutes and the absorbance measured at $569 \mathrm{~nm}$ on a Unicam SP 500 spectrophotometer. The solution was then returned to a test tube and about $5 \mathrm{mg}$ of solid sodium dithionite added. The tube was gently shaken to dissolve the dithionite and left for five minutes to allow complete reduction of methaemalbumin. The absorbance at $569 \mathrm{~nm}$ was again determined and the increase calculated.

Calibration graphs were constructed on five separate occasions. Mean values $( \pm 2 \mathrm{SD})$ are shown in the figure.

Plasmas were obtained from 56 patients admitted for elective surgery or medical outpatients known to have no haemolytic condition. Blood taken from these patients was heparinized, immediately centrifuged, and the plasma stored at $-4 \mathrm{C}$ for a maximum of two days before assay.

The distribution of plasma methaemalbumin values in the 56 normal patients showed a positive skew. The mean was $0.26 \mathrm{mg} / 100 \mathrm{ml}$, and the normal range (mean $\pm 2.36 \times \mathrm{SD}$ ) (Bowker, 1947) was calculated to be 0 to $0.6 \mathrm{mg} / 100 \mathrm{ml}$.

\section{Discussion}

Our normal range of 0 to $0.6 \mathrm{mg} / 100 \mathrm{ml}$ plasma is at 
CALIBRATION CURVES \pm 2 Sn

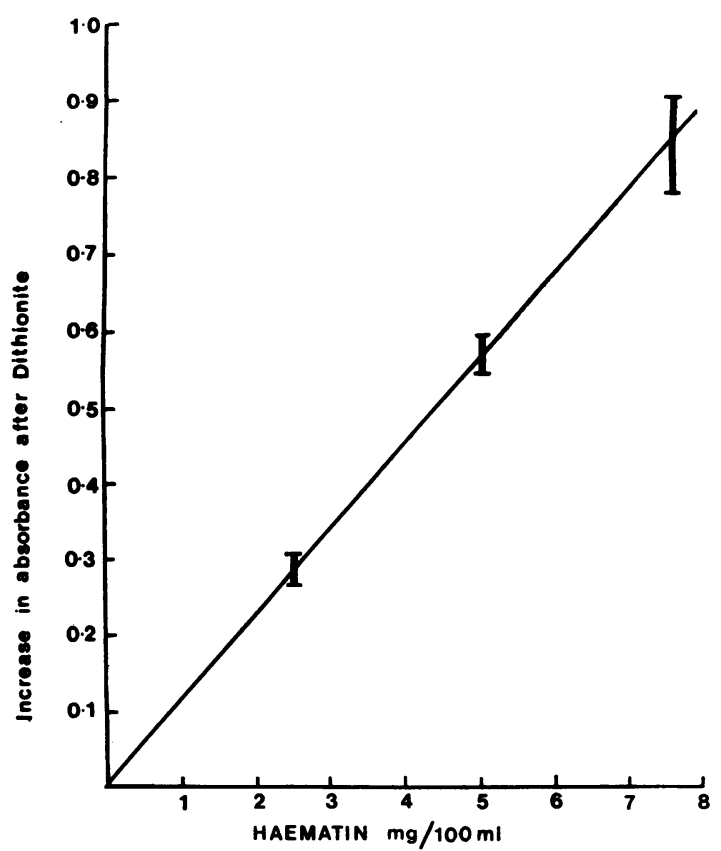

Fig Calibration curves $\pm 2 S D$.

variance with the findings of other authors (Joseph, Stevens, and Longmire, 1968; Kelly, Klein, Porquez, and Homer, 1972; Winstone, 1965) who report a normal range of 0 to $8 \mathrm{mg} / 100 \mathrm{ml}$ using the method of Shinowara and Walters (1963). This discrepancy is due to the fact that in the Shinowara and Walters method plasma methaemalbumin concentration is expressed in terms of haemoglobin.

It is clearly desirable that different methods for measuring plasma methaemalbumin should give comparable results.
Since standard solutions of methaemalbumin can be prepared much more readily from haematin than from haemoglobin it is suggested that the methaemalbumin concentration should be expressed in terms of haematin rather than haemoglobin.

The concentration of methaemalbumin in terms of haematin may be calculated from the Shinowara result as follows:

$\mathrm{mg}$ of haematin $\%=\mathrm{mg}$ of $\mathrm{Hb} \% \times$

$$
\begin{aligned}
\times \frac{\text { mw of haematin }}{\text { mw of haemoglobin }} & \frac{(=652)}{(=16115)} \\
=m g \text { of } \mathrm{Hb} \% & \times 0.04
\end{aligned}
$$

We should like to thank Mrs G. Francey for her technical assistance.

\section{References}

Bowker, A. H. (1947). In Selected Techniques of Statistical Analysis, edited by C. Eisenhart, M. W. Hastay, and W. A. Wallis, p. 97. McGraw-Hill, New York.

Chong, G. C., and Owen, J. A. (1967). Determination of methaemalbumin in plasma. J. clin. Path. 20, 211-212.

Dacie, J. V. (1954). The Haemolytic Anaemias, p. 7. Churchill, London.

Fairley, N. H. (1941). Methaemalbumin. Part I.Clinical aspects. Quart. J. Med., 10, 95-114.

Joseph, W. L., Stevens, G. H., and Longmire, W.P., Jr. (1968). Methemalbumin in the diagnosis of acute pancreatitis. J. surg. Res., 8, 206-210.

Kelly, T. R., Klein, R. L., Porquez, J. M., and Homer, G. M. (1972). Methemalbumin in acute pancreatitis: an experimental and clinical appraisal. Ann. Surg., 175, 15-18.

Laurell, C. B., and Nyman, M. (1957). Studies on the serum haptoglobin level in hemoglobinemia and its influence on renal excretion of hemoglobin. Blood, 12, 493-506.

Northam, B. E., Rowe, D. S., and Winstone, N. E. (1963). Methaemalbumin in the differential diagnosis of acute haemorrhagic and oedematous pancreatitis. Lancet, 1, 348-352.

Northam, B. E., Winstone, N. E., and Banwell, J. G. (1965). In Recent Advances in Gastroenterology, edited by J. Badennoch, and N. B. Brook, p. 354. Churchill, London, Little Brown, Boston.

Shinowara, G. Y., and Walters, M. I. (1963). Hematin-studies on protein complexes and determination in human plasma. Amer. J. clin. Path., 40, 113-122.

Winstone, N. E. (1965). Methaemalbumin in acute pancreatitis. Brit. J. Surg., 52, 804-808. 